\title{
Bird flu data languish in Chinese journals
}

\section{David Cyranoski, Tokyo}

Potentially alarming findings on the avian influenza epidemic currently sweeping southeast Asia went largely unnoticed because they were published in Chinese-language journals, it emerged last week.

Chinese researchers reported this January that the strain of the bird flu virus involved, known as $\mathrm{H} 5 \mathrm{~N} 1$, had infected pigs. This is a cause for concern, as some virologists believe that previous human flu pandemics, such as the one in 1918 that killed millions, originated in pigs. Yet neither the World Health Organization (WHO) nor the UN Food and Agriculture Organization (FAO) was aware of the results when they were published. Last week both groups were hurriedly trying to get the papers translated.

The findings became widely known only when an author on the papers, virologist Chen Hualan of Harbin Veterinary Research Institute in northeast China, presented them at the International Symposium on the Prevention and Control of SARS and Avian Influenza in Beijing on 20 August. The results, which show that the virus was found in 2003 in pigs in southeast China, were originally published in January (L. I. Haiyan et al. Chin. J. Prev. Vet. Med. 26, 1-6; 2004). A second paper by Chen and her colleagues appeared in May, reporting similar results

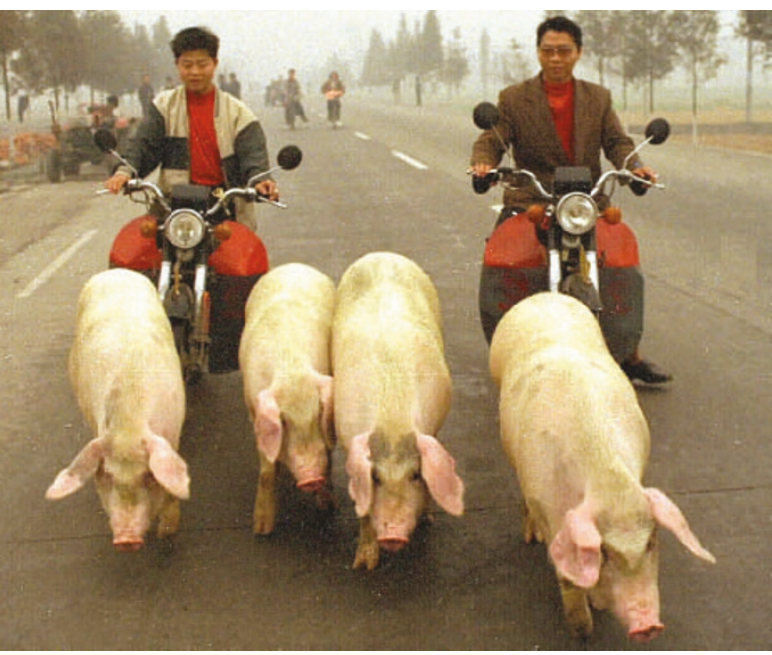

Rotten swine: pigs could host viruses, brewing a human pandemic.

widespread in pigs from southeast China. Pigs are an "ideal mixing vessel", he says. "It is certainly sufficient to make me concerned."

The H5N1 virus has spread through most of southeast Asia this year, resulting in the destruction of over 100 million chickens, including 9 million in China. In Vietnam and Thailand, 37 human infections have been reported, with 26 deaths.

The abstract to Chen's January article ends with the warning that "urgent attention should be paid to the pandemic preparedness of these two subtypes of influenza". But the results attracted no attention outside China before last week. The WHO and the FAO are now waiting to see a translation of the article and to hear

from pigs tested elsewhere in 2001 and 2003 (L. I. Haiyan et al. Chin. J. Vet. Sci. 24, 304-309;2004).

The H5N1 strain, which can be fatal to humans, does not jump easily from birds to humans or between humans. But this might change if pigs are infected, says Malik Peiris, a virologist at teh University of Hong Kong . The virus could exchange genes with the human flu strains that infect pigs and combine to become far more infectious to humans, he warns. Peiris's group has already shown that a human virus, $\mathrm{H} 3 \mathrm{~N} 2$, can coexist with other avian influenza viruses and is from the Chinese agriculture ministrybefore deciding what steps to take. Until then, they urge caution and say that the significance of the findings cannot yet be judged.

The ministry, which seemed to be surprised by the disclosure, moved to calm fears after the news broke. A ministry press release, issued on 23 August, stated that tests on "over 1.1 million samples of poultry and some samples of pigs" conducted this year showed no evidence of H5N1. Officials add that routine testing by Hong Kong researchers of imported pigs had also not turned up evidence of $\mathrm{H} 5 \mathrm{~N} 1$.

\section{Greenland ice sheet to get underhand inspection}

Marine scientists are to take a second stab at a world first - the exploration of the dark waters below the permanent polar ice sheets.

Early next month, the robot submarine Autosub will slide beneath the fringes of the ice sheet that blankets Greenland. Researchers hope to use the vessel to study the underside of the permanent ice, to investigate rising sea levels.

The mission will be the vessel's second such attempt; Autosub was to be deployed under Antarctica's Pine Island Glacier in early 2003, but the ship on which it was being transported was blocked by rapidly drifting ice. Robot subs have previously journeyed under sea ice, which breaks up and reforms annually, but none has attempted to go under permanent ice.

Sea ice is often only a few metres thick, but the ice shelf that Autosub will explore is 200 metres deep and likely to contain narrow channels in which the sub could get irretrievably stuck or lost. In addition,

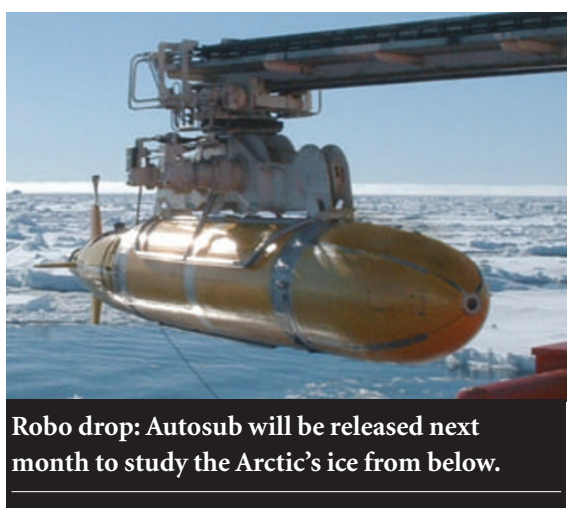

unexpected changes in salinity could create buoyancy problems that might sink the vessel or force it up into the ice. Strong currents could also send the sub off course.

"This very much is undersea space exploration," says Ken Collins of the Southampton Oceanography Centre and the expedition's scientific coordinator. "If anything goes wrong far out there, we won't see it again." Collins and his colleagues on board the James Clark Ross have spent the past two weeks sending Autosub on only slightly less perilous missions under the transient sea ice, awaiting the return of the vessel — worth roughly $\mathfrak{£ 1 . 5}$ million (US\$2.7 million) — like worried parents.

The 7-metre-long robot, powered by some 5,000 household batteries, is programmed to map the contours and biology of the sea bed, to measure the thickness of ice overhead and to collect sea water for analysis back on the ship. Together, the results should improve understanding of how fresh water from the ice is cycled into the ocean, contributing to rises in sea level.

"The effects of global warming are greatest and fastest in the Arctic," says Peter Wadhams, a polar scientist from the University of Cambridge, UK, who is leading part of the expedition. "The Arctic ice has decreased in thickness by $40 \%$ over the past 20 years, so by 2080 the Arctic will be ice-free in summer."

www.soc.soton.ac.uk/aui 